\title{
Is the neutrophil/lymphocyte rate as effective as CURB-65 in the patient management of the community-acquired pneumonia patients admitted to the Emergency Medicine?
}

\author{
İlker Barut๑, Melih Yükselø, Halil Kaya๑, Zülfi Engindeniz $\odot$
}

Department of Emergency Medicine, University of Health Sciences, Bursa Yüksek Ihtisas Training and Research Hospital, Bursa, Turkey

\begin{abstract}
Objectives: The aim of this study was to identify the patients with community-acquired pneumonia (CAP) in emergency departments, and to compare CURB-65 scoring system and Netrofil/Lymphocyte Ratio (NLO) which are some of the commonly used blood parameters to make an inpatient or outpatient decision quickly and effectively.

Methods: This study was performed retrospectively by examining the files of 442 patients who were admitted to the adult emergency department of Bursa Yüksek İhtisas Training and Research Hospital between September 1, 2017 and October 31, 2018. The demographic characteristics, physical examination findings, laboratory results, hospitalizations, and CURB-65 scores of the patients included in the study were recorded on a preprepared paper and electronic form and statistical analyzes of these data were conducted.

Results: Two hundred and fifty-five (57.69\%) patients were male and the mean age was 70.93 years. The mean NLO value was 9.85 , the mean MPV value was 8.62 , the mean eosinophil value was 0.15 and the mean CURB65 score was 1.85 . When the post hoc paired group comparison was conducted for the mean NLR, it was found that the other groups differed from each other except the groups admitted to the intensive care unit and the service. Glasgow Coma Scale score and CURB-65 score were found to be significant predictors for hospitalization to service and intensive care unit $(p<0.05)$.

Conclusions: We think that NLR may be useful in decision-making process, especially in prospective studies, although the use of NLR in patients with CAP is not statistically significant. In this study, we also examined that CURB-65 is an effective scoring system in the management of this patient group.

Keywords: Emergency department, community-acquired pneumonia, CURB-65, Netrofil/lymphocyte ratio
\end{abstract}

$P^{\prime}$ neumonia is an acute infection of the lung parenchyma and is one of the major causes of morbidity and mortality [1]. According to World Health Organization data, it is the 4th most common cause of death worldwide [2]. Pneumonia is the third most common cause of hospitalization in the USA and causes an average of 544,000 hospitalizations from the emergency departmentper year [3]. Communityacquired pneumonia (CAP) is defined as an acute lung infection involving alveoli in patients who have not recently received medical care [4]. CAP causes significant morbidity and mortality, especially in the elderly patients and patients with significant comorbidity. CAP is affected by the patient's comorbidities and 
may alter the course of existing diseases and decompensate them. Therefore, the main problem for CAP in the emergency department is to define the patient who will experience acute respiratory failure or multiple organ failure [5-7].

Various decision support systems are being developed to evaluate the pneumonia clinic. Pneumonia Severity Index (PSI), which emerged in 1997, and CURB-65, a scale of confusion, uremia, respiratory rate, blood pressure and parameters above 65 years of age, proposed in 2003, are two current and frequently used examples $[8,9]$.

Neutrophil/lymphocyte Ratio (NLR) is a simple parameter used to easily assess a person's inflammatory state. NLR has been recognized not only as an indicator of acute viral or bacterial infection but also as a marker of the systemic inflammatory response in some studies [10]. It has been shown to be used as a risk factor in determining the prognosis and mortality of sepsis, pulmonary embolism, cardiovascular system and neurovascular diseases [11-14].

The aim of this study was to define the patients with CAP in the emergency department and to compare NLR and CURB-65 scoring system, which aresome of the commonly used blood parameters to decide the inpatient or outpatient treatment quickly and effectively.

\section{METHODS}

Patients who were admitted to the adult emergency department of Bursa Higher Specialization Training and Research Hospitalbetween September 2017 and October 2018 and diagnosed as CAP were included in this retrospective single-center study. A total of 2,000 patients were diagnosed as CAP and 442 patients were included in the study with the exclusion of patients who could not provide data adequacy, who had recently received major trauma, malignancy treatment or subsequent malignancy diagnosis. Demographic characteristics, comorbidities, blood pressure, pulse rate, peripheral saturation, electrocardiogram (ECG) findings, CURB-65 scores, Glasgow Coma Scale (GCS), white cell count, neutrophil, lymphocyte, NLR and eosinophil values, mean platelet volume (MPV), emergency room discharge, service and intensive care unit hospitalization were examined.

\section{Statistical Analysis}

Data were analyzed via SPSS 21.0 (SPSS Inc., Chicago, IL, USA) software. Results were expressed as number, percentage, mean, median, minimum-maximum values, and standard deviation. The "Outcome" variable (Discharge / Admission to the service / Admission to the Intensive Care unit) was used in the analyzes. The suitability of the numerical variables to

Table 1. Descriptive statistics regarding the numerical variables

\begin{tabular}{lccccc}
\hline & Mean & SD & Median & Lowest & Highest \\
\hline Age & 70.93 & 16.32 & 75.00 & 18.00 & 105.00 \\
Systolic blood pressure (mmHg) & 129.36 & 29.52 & 126.50 & 50.00 & 242.00 \\
Diastolic blood pressure (mmHg) & 77.82 & 17.00 & 78.50 & 29.00 & 163.00 \\
Pulse/min & 101.79 & 21.04 & 100.00 & 41.00 & 170.00 \\
\hline Peripheral oxygen saturation (\%) & 90.52 & 7.26 & 92.00 & 54.00 & 100.00 \\
GCS score & 13.89 & 2.00 & 15.00 & 5.00 & 15.00 \\
CURB 65 score & 1.85 & 1.10 & 2.00 & 0.00 & 4.00 \\
White blood cell & 12.84 & 6.58 & 11.60 & 2.35 & 54.90 \\
Neutrophil & 9.89 & 6.17 & 8.30 & 0.40 & 50.50 \\
Lymphocyte & 1.91 & 2.18 & 1.40 & 0.20 & 19.90 \\
NLO & 9.58 & 10.76 & 5.65 & 0.06 & 73.00 \\
MPV & 8.62 & 1.29 & 8.60 & 5.70 & 14.10 \\
Eosinophil & 0.15 & 0.82 & 0.01 & 0.00 & 14.70 \\
\hline
\end{tabular}

$\mathrm{SD}=$ Standard deviation, $\mathrm{GCS}=$ Glasgow Coma Scale, $\mathrm{NLO}=$ Neutrophil/Lymphocyte Ratio 
Table 2. Distribution of numerical variable sex a mined according to out come of patients

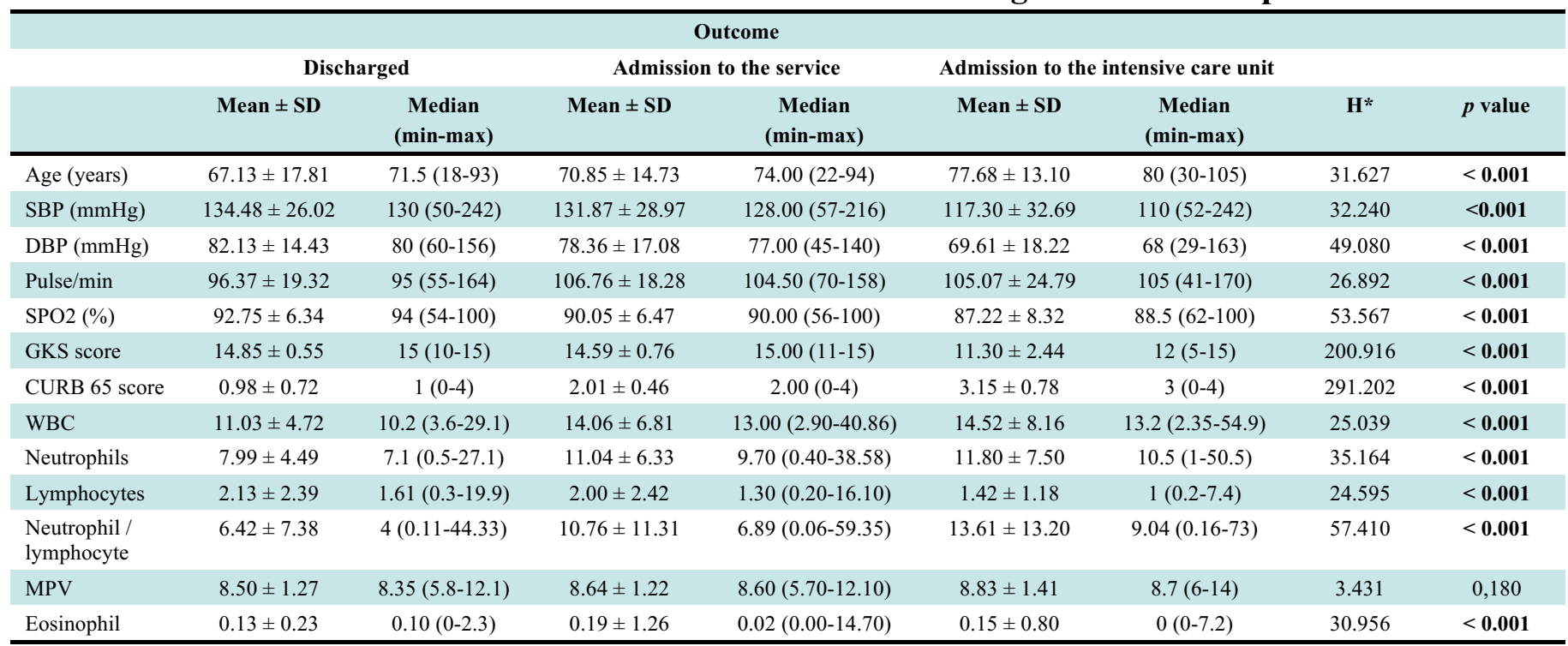

$\mathrm{SBP}=$ systolic blood pressure, $\mathrm{DBP}=$ diastolic blood pressure, $\mathrm{SPO} 2=$ Peripheral oxygen saturation, MPV = mean platelet volume, GCS $=$ Glasgow coma scale, $\mathrm{WBC}=$ White blood cell, ${ }^{*}$ Kruskal-Wallis

normal distribution was examined by the Kolmogorov-Smirnov test. The Chi-square test, Spearman correlation analysis and Kruskal-Wallis analysis were used in pairwise comparisons. Tamhane T2 test was used as post hoc analysis. Multinomial logistic regression analysis was used to answer the question "Can the clinical judgment be measured during hospitalization decision-making?". The statistical significance level was considered as $p<0.05$.

\section{RESULTS}

A total of 442 patients were included in the study. Two hundred and fifty-five $(57.69 \%)$ of the patients were male and $187(42.31 \%)$ were female. The mean age of the patients was 70.93, the mean GCS score was 13.89, the mean CURB-65 score was 1.85 and the mean NLR rate was 9.58 (Table 1). When the outcome of the patients was examined, it was found that $43.9 \%$

Table 3. Pairwise comparison of the mean CURB 65 scores between the groups

\begin{tabular}{|c|c|c|c|c|c|}
\hline \multirow[t]{2}{*}{ (I) Outcome } & \multirow[t]{2}{*}{ (J) Outcome } & \multirow[t]{2}{*}{ Difference (I-J) } & \multirow[t]{2}{*}{$p$ value } & \multicolumn{2}{|c|}{ 95\% Confidence Interval } \\
\hline & & & & Lower & Upper \\
\hline \multirow[t]{2}{*}{ Discharged } & $\begin{array}{l}\text { Admission to the } \\
\text { service }\end{array}$ & -1.023 & $<0.001$ & -1.18 & -0.87 \\
\hline & $\begin{array}{l}\text { Admission to the } \\
\text { intensive care unit }\end{array}$ & -2.169 & $<0.001$ & -2.38 & -1.95 \\
\hline \multirow{2}{*}{$\begin{array}{l}\text { Admission to } \\
\text { the service }\end{array}$} & Discharged & 1.023 & $<0.001$ & 0.87 & 1.18 \\
\hline & $\begin{array}{l}\text { Admission to the } \\
\text { intensive care unit }\end{array}$ & -1.146 & $<0.001$ & -1.35 & -0.94 \\
\hline \multirow{2}{*}{$\begin{array}{l}\text { Admission to } \\
\text { the intensive } \\
\text { care unit }\end{array}$} & Discharged & 2.169 & $<0.001$ & 1.95 & 2.38 \\
\hline & $\begin{array}{l}\text { Admission to the } \\
\text { service }\end{array}$ & 1.146 & $<0.001$ & 0.94 & 1.35 \\
\hline
\end{tabular}




\section{Table 4. Pairwise comparison of the mean neutrophil / lymphocyte ratio between the groups}

\begin{tabular}{|c|c|c|c|c|c|}
\hline \multirow[t]{2}{*}{ (I) Outcome } & \multirow[t]{2}{*}{ (J) Outcome } & \multirow[t]{2}{*}{ Difference (I-J) } & \multirow[t]{2}{*}{$p$ value } & \multicolumn{2}{|c|}{ 95\% Confidence Interval } \\
\hline & & & & Lower & Upper \\
\hline \multirow[t]{2}{*}{ Discharged } & $\begin{array}{c}\text { Admission to the } \\
\text { service }\end{array}$ & -4.34028 & $<0.001$ & -6.9944 & -1.6862 \\
\hline & $\begin{array}{l}\text { Admission to the } \\
\text { intensive care unit }\end{array}$ & -7.19192 & $<0.001$ & -10.4775 & -3.9063 \\
\hline \multirow{2}{*}{$\begin{array}{l}\text { Admission to the } \\
\text { service }\end{array}$} & Discharged & 4.34028 & $<0.001$ & 1.6862 & 6.9944 \\
\hline & $\begin{array}{l}\text { Admission to the } \\
\text { intensive care unit }\end{array}$ & -2.85164 & 0.203 & -6.6590 & 0.9557 \\
\hline \multirow{2}{*}{$\begin{array}{l}\text { Admission to the } \\
\text { intensive care unit }\end{array}$} & Discharged & 7.19192 & $<0.001$ & 3.9063 & 10.4775 \\
\hline & $\begin{array}{c}\text { Admission to the } \\
\text { service }\end{array}$ & 2.85164 & 0.203 & -0.9557 & 6.6590 \\
\hline
\end{tabular}

were discharged, $31.0 \%$ were hospitalized in the service and $25.1 \%$ were hospitalized in the intensive care unit. On the other hand, when the outcome of the patients and numerical variables were compared, it was seen that all variables except MPV differed between the groups (Table 2).

When post hoc paired group comparisons were conducted for CURB 65 mean scores, it was found that all groups differed from each other (Table 3). When the post hoc paired group comparison was conducted for the mean NLR, it was found that the other groups differed from each other except the groups that were admitted to the intensive care unit and the service (Table 4).

When the pairwise correlations between numerical variables are examined, it is considered that many variables are related to each other (Table 5).

A multinomial logistic regression analysis was performed to investigate the independent factors affecting the outcome of the emergency department of the patients, which is the main outcome measure of the study. Among the variables that were found significant in pairwise comparisons, age, systolic blood pressure, diastolic blood pressure, pulse, peripheral oxygen saturation, GCS score, CURB-65 score, BK, NLR and Eosinophil were taken ascovarianceto the regression model. Discharge status was taken as the reference category. In the regression analysis, a
Nagelkerke R square value of $82.0 \%$ was obtained. GCS score and CURB-65 score were found to be significant predictors for hospitalization and intensive care unit admission (Table 6).

\section{DISCUSSION}

CAP increases the number of hospital admissions and treatment costs worldwide. It is also responsible for a significant portion of labor losses and mortality $[15,16]$. Annual incidence in Europe is reported to be $0.5-1.1 \%$ [17]. In a study conducted in Finland, the frequency of pneumonia was11.6 / 1000 persons annually, and hospitalization rates werefound to be $2.67 / 1,000$ for males and 1.10/1,000 for females [18]. In the USA, there were $107-370$ cases per 100,000 between the ages of 18-64, whereas there were 6305,697 cases per 100,000 over 65 years [19]. In our country, according to the results of a project carried out by the Ministry of Health, RefikSaydam National Public Health Agency and Baskent University, pneumonia was the 15 th with a frequency of $1.15 \%$ among the first 20 acute and chronic diseases diagnosed by physicians [20]. In our study, the incidence of CAP was $0.4 \%$, which is contrary to the literature. This may be due to the presence of a Chest Diseases Hospital in a location that is very close to our hospital, and thus, 
Table 5. Correlations between numerical variables

\begin{tabular}{|c|c|c|c|c|c|c|c|c|c|c|c|c|c|}
\hline & & SBP & DBP & Pulse & POS & GKS & CURB 65 & WB & Neutrophil & Lymphocyte & $\mathbf{N} / \mathbf{L}$ & MPV & Eosinophil \\
\hline \multirow[t]{2}{*}{ Age } & $\mathrm{r}$ & -0.008 & -0.069 & -0.010 & -0.115 & -0.182 & 0.357 & -0.045 & -0.001 & -0.126 & 0,107 & $-0,014$ & $-0,070$ \\
\hline & $p$ & 0.860 & 0.147 & 0.832 & 0.016 & $<0.001$ & $<0.001$ & 0.343 & 0.979 & 0.008 & 0,025 & 0,773 & 0,144 \\
\hline \multirow[t]{2}{*}{ SBP } & $\mathrm{r}$ & & 0.680 & -0.066 & 0.014 & 0.309 & -0.229 & -0.171 & -0.183 & 0.075 & $-0,187$ & $-0,008$ & 0,135 \\
\hline & $p$ & & $<0.001$ & 0.169 & 0.769 & $<0.001$ & $<0.001$ & $<0.001$ & $<0.001$ & 0.114 & $<0.001$ & 0,860 & 0,005 \\
\hline \multirow[t]{2}{*}{ DBP } & $\mathrm{r}$ & & & -0.020 & 0.047 & 0.282 & -0.301 & -0.139 & -0.159 & 0.066 & $-0,154$ & $-0,022$ & 0,098 \\
\hline & $p$ & & & 0.675 & 0.325 & $<0.001$ & $<0.001$ & 0.003 & 0.001 & 0.169 & 0,001 & 0,643 & 0,040 \\
\hline \multirow[t]{2}{*}{ Pulse } & $\mathrm{r}$ & & & & -0.156 & -0.141 & 0.181 & 0.204 & 0.203 & -0.059 & 0,175 & 0,089 & $-0,130$ \\
\hline & $p$ & & & & 0.001 & 0.003 & $<0.001$ & $<0.001$ & $<0.001$ & 0.221 & $<0.001$ & 0,064 & 0,006 \\
\hline \multirow[t]{2}{*}{ SPO2 } & $\mathrm{r}$ & & & & & 0.280 & -0.336 & -0.098 & -0.106 & 0.108 & $-0,146$ & 0,027 & 0,122 \\
\hline & $p$ & & & & & $<0.001$ & $<0.001$ & 0.040 & 0.026 & 0.023 & 0,002 & 0,577 & 0,010 \\
\hline \multirow[t]{2}{*}{ GKS } & $\mathrm{r}$ & & & & & & -0.615 & -0.137 & -0.154 & 0.172 & $-0,243$ & $-0,117$ & 0,220 \\
\hline & $p$ & & & & & & $<0.001$ & 0.004 & 0.001 & $<0.001$ & $<0.001$ & 0,014 & $<0.001$ \\
\hline \multirow[t]{2}{*}{ CURB 65} & $\mathrm{r}$ & & & & & & & 0.182 & 0.224 & -0.233 & 0,328 & 0,066 & $-0,253$ \\
\hline & $p$ & & & & & & & $<0.001$ & $<0.001$ & $<0.001$ & $<0.001$ & 0,166 & $<0.001$ \\
\hline \multirow[t]{2}{*}{ WB } & $\mathrm{r}$ & & & & & & & & 0.924 & 0.148 & 0,448 & 0,038 & $-0,102$ \\
\hline & $p$ & & & & & & & & $<0.001$ & 0.002 & $<0.001$ & 0,427 & 0,031 \\
\hline \multirow[t]{2}{*}{ Neutrophil } & $\mathrm{r}$ & & & & & & & & & -0.041 & 0,633 & 0,060 & $-0,162$ \\
\hline & $p$ & & & & & & & & & 0.390 & $<0.001$ & 0,211 & 0,001 \\
\hline \multirow[t]{2}{*}{ Lymphocyte } & & & & & & & & & & & $-0,764$ & 0,054 & 0,404 \\
\hline & $p$ & & & & & & & & & & $<0.001$ & 0,261 & $<0.001$ \\
\hline \multirow[t]{2}{*}{ NLR } & $\mathrm{r}$ & & & & & & & & & & & 0,002 & $-0,405$ \\
\hline & $p$ & & & & & & & & & & & 0,967 & $<0.001$ \\
\hline \multirow[t]{2}{*}{ MPV } & $\mathrm{r}$ & & & & & & & & & & & & 0,107 \\
\hline & $p$ & & & & & & & & & & & & 0.024 \\
\hline
\end{tabular}

$\mathrm{SBP}=$ Systolic blood pressure, $\mathrm{DBP}=$ Diastolic blood pressure, $\mathrm{SPO} 2=$ Peripheral oxygen saturation, GCS $=$ Glasgow coma scale, $\mathrm{WB}=$ White blood cell, NLR = Neutrophil/lymphocyte ratio, MPV = Mean platelet volume

the majority of patients go to this center.

According to insurance companiesdata in Germany, $46.5 \%$ of 660,000 CAP cases were hospitalized per year and the majority of these patients are over 60 years of age $[21,22]$. In another study conducted in Germany, the mean age was 76 for hospitalized patients [23]. Another study conducted in Australia found the rate of hospitalizations as 563 per 100,000 in the 65 to 74 age group [24]. In our study, the mean age of the patients who were discharged was 67.17 , the mean age of the patients who were hospitalized in the service was 70.85 and the mean age of the patients who were admitted to the intensive care unit was 77.68. The mean age of the hospitalized patients in our study was consistent with other studies in the literature.

In a study conducted in the UK, approximately $1 / 3$ of CAP patients were treated as inpatient and $2 / 3$ of them were treated as outpatients. In that study, hospi- tal-acquired pneumonia and aspiration pneumonia were excluded [25]. In another study, the incidence of pneumonia was $567 / 100,000$ per year, and $48 \%$ of patients with pneumonia were hospitalized [26]. In a study conducted in the United States, the rate of hospitalization was identified as 24.8 per 10,000 adults [19]. In our study, $56 \%$ of the patients were hospitalized. Correlation with mean and median age increase in patients with intensive care and service hospitalization is a general result that was found in our study and consistent with the literature. As the age increases, the physical capacity decreases and the decompensation rates due to the comorbidities also increase, which has a negative effect on recovery times and the intensity of the health services [27].

While CURB -65 is recommended in European countries such as England and Sweden, PSI is mostly used in the US and Australia. It is observed that CURB-65 and PSI scoring systems have negative pre- 
Table 6. Multinomial logistic regression analysis

\begin{tabular}{llcccccc}
\hline Outcome & & $\mathbf{B}$ & Wald & $\boldsymbol{p}$ value & $\mathbf{E x p ( B )}$ & $\begin{array}{c}\text { 95\% confidence interval } \\
\text { Lower }\end{array}$ & Upper \\
\hline $\begin{array}{l}\text { Admission to the } \\
\text { service }\end{array}$ & Constant & 4.720 & 1.383 & 0.240 & & & \\
& & & & & & & \\
& Age & -0.014 & 1.567 & 0.211 & 0.987 & 0.966 & 1.008 \\
& Systolic blood pressure & 0.012 & 2.029 & 0.154 & 1.012 & 0.996 & 1.028 \\
& Diastolic blood pressure & -0.024 & 2.826 & 0.093 & 0.976 & 0.950 & 1.004 \\
& Pulse & 0.024 & 7.757 & $\mathbf{0 . 0 0 5}$ & 1.024 & 1.007 & 1.041 \\
& Peripheral oxygen & -0.043 & 3.265 & 0.071 & 0.958 & 0.914 & 1.004 \\
& saturation & & & & & & \\
& GKS score & -0.470 & 4.727 & $\mathbf{0 . 0 3 0}$ & 0.625 & 0.409 & 0.955 \\
& CURB 65 score & 2.550 & 73.891 & $<\mathbf{0 . 0 0 1}$ & 12.812 & 7.163 & 22.917 \\
& WB & 0.047 & 2,198 & 0.138 & 1.048 & 0.985 & 1.114 \\
& Neutrophil/lymphocyte & 0.025 & 1.425 & 0.233 & 1.025 & 0.984 & 1.067 \\
& Eosinophil & 0.092 & 0.130 & 0.719 & 1.096 & 0.665 & 1.809 \\
Admission to the & Constant & 21.654 & 15.489 & $<\mathbf{0 . 0 0 1}$ & & & \\
intensive care unit & & & & & & \\
& Age & 0.014 & 0.384 & 0.536 & 1.014 & 0.971 & 1.058 \\
& Systolic blood pressure & 0.013 & 0.887 & 0.346 & 1.013 & 0.986 & 1.040 \\
& Diastolic blood pressure & -0.037 & 2.725 & 0.099 & 0.964 & 0.923 & 1.007 \\
& Pulse & 0.008 & 0.360 & 0.549 & 1.008 & 0.981 & 1.037 \\
& Peripheral oxygen & -0.073 & 3.350 & 0.067 & 0.930 & 0.860 & 1.005 \\
& saturation & & & & & & \\
& GKS score & -1.919 & 55.439 & $<\mathbf{0 . 0 0 1}$ & 0.147 & 0.089 & 0.243 \\
& CURB 65 score & 4.843 & 87.966 & $<\mathbf{0 . 0 0 1}$ & 126.814 & 46.096 & 348.878 \\
& WB & 0.037 & 0.520 & 0.471 & 1.038 & 0.939 & 1.147 \\
& Neutrophil/lymphocyte & 0.020 & 0.388 & 0.533 & 1.020 & 0.958 & 1.086 \\
\hline & Eosinophil & 0.205 & 0.528 & 0.467 & 1.228 & 0.706 & 2.136 \\
\hline
\end{tabular}

Reference category $=$ Discharged

dictive values but relatively low positive predictive values [28]. The increase in hospitalization rates with CURB-65 is an expected result since it is the standard criterion in the study. In our study, CURB-65 score was found to be significant predictors for both hospitalizations to service and intensive care unit.

NLR, MPV and eosinophil values that we usedas blood parameters have been investigated in various studies to confirm the presence of infection and to evaluate clinical progression $[29,30]$. In a previous study in our country, the NLR value in healthy population was found to be 1.7. In other studies, values were determined as 1.68 to 1.9 [31]. The NLR value gradually increases until the age of 20 , a plateau period is reached and the NLR value increasesover the age of 60 . This increase, especially over the age of 60 , can be due to physiological conditions such as menopause and andropause. The mean NLR was found to be 2.96 in males and 2.49 in females over the age of 70 years [31]. It was reported that the NLR values in CAP were over 13 in inpatients and 18in the patients who were followed up in the intensive care unit. The mortality rate was higher in patients with NLR values of 23 and over [32]. NLR has been previously described as a predictor of bacteremia [33]. A value of $<3.0$ for NLR may be used to prove the absence of infection, while a value of $>10$, when taken as a cut off value, is efficient enough to be considered equivalent to other infection predictors such as CRP, PCT [29, 34]. The decrease in lymphocyte value was found to be determinant in the decision of hospitalization in the intensive care unit.

Even though there are favorable or unfavorable studies regarding the effectiveness of their individual use, it was stated even in th eunfavorable studies that they should be considered when deciding discharge / outpatient treatment or hospitalization [32]. In our study, the mean NLR value was found to be 10.76 in the inpatients and 13.61 in the intensive care unit patients. Although NLR value was significantly different in pairwise comparisons, it did not become statistically significant when evaluated as a whole. 


\section{Limitations}

As the study was performed retrospectively, history, some of the vital signs and comorbidities were not examined sufficiently. In addition, short, medium and long-term morbidity and mortality rates could not be determined in this study, which is a limitation of the study. A prospective study may investigate this issue.

\section{CONCLUSION}

In conclusion, we think that NLR may be useful in decision-making process, especially in prospective studies, although the use of NLR in patients with CAP is not statistically significant. In this study, we also examined that CURB-65 is an effective scoring system in the management of this patient group.

\section{Authors' Contribution}

Study Conception: İB, HK, ZE, MY; Study Design: İB, HK, ZE, MY; Supervision: İB, HK, ZE, MY; Funding: İB, HK, ZE; Materials: İB, HK, ZE; Data Collection and/or Processing: İB, HK, ZE, MY; Statistical Analysis and/or Data Interpretation: İB, HK, ZE, MY; Literature Review: İB, HK, ZE, MY; Manuscript Preparation: İB, HK, MY and Critical Review: HK, MY.

\section{Conflict of interest}

The authors disclosed no conflict of interest during the preparation or publication of this manuscript.

\section{Financing}

The authors disclosed that they did not receive any grant during conduction or writing of this study.

\section{REFERENCES}

1. Lanks CW, Musani AI, Hsia DW. Community-acquired pneumonia and hospital-acquired pneumonia. Med Clin North Am 2019;103:487-501.

2. The 10 leading causes of death in the world: World Health Organization 2018. Available from: https://www.who.int/newsroom/fact-sheets/detail/the-top-10-causes-of-death.

3. Rider AC, Frazee BW. Community-acquired pneumonia. Emerg Med Clin North Am 2018;36:665-83.

4. Musher DM, Thorner AR. Community-acquired pneumonia.
N Eng J Med 2014;371:1619-28.

5. Janssens JP, Krause KH. Pneumonia in the very old. Lancet Infect Dis 2004;4:112-24.

6. Bellelli G, Guerini F, Cerri AP, Trabucchi M. A sudden decline in mobility status as an early sign of acute infection in elderly patients: evidence from three case reports. Aging Clin Exp Res 2012;24:281-4.

7. Khokhar SR, Stern Y, Bell K, Anderson K, Noe E, Mayeux R, et al. Persistent mobility deficit in the absence of deficits in activities of daily living: a risk factor for mortality. J Am Geriatr Soc 2001;49:1539-43.

8. Lim WS, van der Eerden MM, Laing R, Boersma WG, Karalus $\mathrm{N}$, Town GI, et al. Defining community acquired pneumonia severity on presentation to hospital: an international derivation and validation study. Thorax 2003;58:377-82.

9. Fine MJ, Auble TE, Yealy DM, Hanusa BH, Weissfeld LA, Singer DE, et al. A prediction rule to identify low-risk patients with community-acquired pneumonia. N Eng J Med 1997;336:243-50.

10. Li J, Chen Q, Luo X, Hong J, Pan K, Lin X, et al. Neutrophil-to-lymphocyte ratio positively correlates to age in healthy population. J Clin Lab Anal 2015;29:437-43.

11. Hwang SY, Shin TG, Jo IJ, Jeon K, Suh GY, Lee TR, et al. Neutrophil-to-lymphocyte ratio as a prognostic marker in critically-ill septic patients. Am J Emerg Med 2017;35:234-9.

12. Jia D, Liu F, Zhang Q, Zeng GQ, Li XL, Hou G. Rapid onsite evaluation of routine biochemical parameters to predict right ventricular dysfunction in and the prognosis of patients with acute pulmonary embolism upon admission to the emergency room. J Clin Lab Anal 2018;32:e22362.

13. Wang X, Zhang G, Jiang X, Zhu H, Lu Z, Xu L. Neutrophil to lymphocyte ratio in relation to risk of all-cause mortality and cardiovascular events among patients undergoing angiography or cardiac revascularization: a meta-analysis of observational studies. Atherosclerosis. 2014;234:206-13.

14. Gokhan S, Ozhasenekler A, Mansur Durgun H, Akil E, Ustundag M, Orak M. Neutrophil lymphocyte ratios in stroke subtypes and transient ischemic attack. Eur Rev Med Pharmacol Sci 2013;17:653-7.

15. Pinner RW, Teutsch SM, Simonsen L, Klug LA, Graber JM, Clarke MJ, et al. Trends in infectious diseases mortality in the United States. JAMA 1996;275:189-93.

16. Acute respiratory infections in under-fives: 15 million deaths a year. Lancet (London, England). 1985;2:699-701.

17. BTS Guidelines for the Management of Community Acquired Pneumonia in Adults. Thorax 2001;56 Suppl 4:Iv1-64. 18. Jokinen C, Heiskanen L, Juvonen H, Kallinen S, Karkola K, Korppi M, et al. Incidence of community-acquired pneumonia in the population of four municipalities in eastern Finland. Am J Epidemiol 1993;137:977-88.

19. Jain S, Self WH, Wunderink RG, Fakhran S, Balk R, Bramley $\mathrm{AM}$, et al. Community-acquired pneumonia requiring hospitalization among US adults. N Eng J Med 2015;373:41527.

20. Başkent Üniversitesi Ulusal Hastalık Yükü ve Maliyeti Etkinlik Projesi.TC Sağlık Bakanlığı Sağlık İstatistikleri Yıllığı.Refik Saydam Hıfzıssıhha Merkezi Başkanlığı Hıfzıssıhha Mektebi 
Müdürlüğü.2004.

21. Breitling LP, Saum KU, Schottker B, Holleczek B, Herth FJ, Brenner H. Pneumonia in the noninstitutionalized older population. Dtsch Arztebl Int 2016;113:607-14.

22. Kolditz M, Tesch F, Mocke L, Hoffken G, Ewig S, Schmitt J. Burden and risk factors of ambulatory or hospitalized CAP: A population based cohort study. Respir Med 2016;121:32-8.

23. Kolditz M, Ewig S. Community-acquired pneumonia in adults. Dtsch Arztebl Int 2017;114:838.

24. Dirmesropian S, Liu B, Wood JG, MacIntyre CR, McIntyre $\mathrm{P}$, Karki S, et al. Pneumonia hospitalisation and case-fatality rates in older Australians with and without risk factors for pneumococcal disease: implications for vaccine policy. Epidemiol Infect 2019; 147:e118.

25. Guest JF, Morris A. Community-acquired pneumonia: the annual cost to the National Health Service in the UK. Eur Respir J 1997; 10:1530-4.

26. Cataudella E, Giraffa CM, Di Marca S, Pulvirenti A, Alaimo S, Pisano M, et al. Neutrophil-to-lymphocyte ratio: an emerging marker predicting prognosis in elderly adults with communityacquired pneumonia. J Am Geriatr Soc 2017;65:1796-801.

27. Rozenbaum MH, Mangen MJ, Huijts SM, van der Werf TS, Postma MJ. Incidence, direct costs and duration of hospitalization of patients hospitalized with community acquired pneumonia: a nationwide retrospective claims database analysis. Vaccine 2015;33:3193-9.

28. Marrie T, Lau C, Wheeler S, Wong C, Vandervoort M, Fea- gan B, et al. A controlled trial of a critical pathway for treatment of community-acquired pneumonia. Community-Acquired Pneumonia Intervention Trial Assessing Levofloxacin. JAMA 2000;283:749-55.

29. Karakonstantis S, Kalemaki D, Tzagkarakis E, Lydakis C. Pitfalls in studies of eosinopenia and neutrophil-to-lymphocyte count ratio. Infect Dis 2018;50:163-74.

30. Rodriguez-Fernandez A, Andaluz-Ojeda D, Almansa R, Justel M, Eiros JM, Ortiz de Lejarazu R. Eosinophil as a protective cell in S. aureus ventilator-associated pneumonia. Mediators Inflamm 2013;2013:152943.

31. Aydın İ, Ağıllı M, Aydın FN, Kurt YG, Çaycı T, Taş A, et al. [The reference ranges of neutrophil-lymphocyte ratio in different age groups]. Gülhane Tıp Derg 2015;57:414-8. [Article in Turkish]

32. De Jager CP, Wever PC, Gemen EF, Kusters R, van Gageldonk-Lafeber AB, van der Poll $T$, et al. The neutrophil-lymphocyte count ratio in patients with communityacquired pneumonia. PloS One 2012;7:e46561.

33. Zahorec R. Ratio of neutrophil to lymphocyte counts--rapid and simple parameter of systemic inflammation and stress in critically ill. Bratisl Lek Listy 2001;102:5-14.

34. Ljungstrom L, Pernestig AK, Jacobsson G, Andersson R, Usener B, Tilevik D. Diagnostic accuracy of procalcitonin, neutrophil-lymphocyte count ratio, C-reactive protein, and lactate in patients with suspected bacterial sepsis. PloS One 2017; 12:e0181704. 